\title{
Dark Tourism Sites in India: A Review
}

\author{
Swapnil P Dhatrak \\ Assistant Professor, Department of Geography, LVH College, Nashik, Maharashtra, India \\ https://orcid.org/0000-0002-8268-544X
}

\section{OPEN ACCESS}

Manuscript ID:

ASH-2020-08023328

Volume: 8

Issue: 2

Month: October

Year: 2020

P-ISSN: 2321-788X

E-ISSN: 2582-0397

Received: 26.08.2020

Accepted: 28.09.2020

Published: 01.10.2020

Citation:

Dhatrak, Swapnil P. "Dark Tourism Sites in India:

A Review." Shanlax

International Journal

of Arts, Science and

Humanities, vol. 8, no. 2, 2020, pp. 53-57.

DOI:

https://doi.org/10.34293/

sijash.v8i2.3328

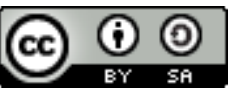

This work is licensed under a Creative Commons Attribution-ShareAlike 4.0 International License

\begin{abstract}
The study of this paper aims to study the various sites of dark tourism in India. Tourism in India is important for the country's economy and its sectors growing rapidly. Tourism means the act and process of spending time away from home in pursuit of recreation, relaxation, and pleasure while making use of the commercial provision. There are many forms of tourism based on the purpose of visit.in that paper; we discussed dark tourism development and sites in India. Dark tourism (black tourism, morbid tourism) has been defined as tourism involving travel to places historically associated with death and tragedy, planning a project on dark tourism documenting the increasing popularity of morbid landmarks around the world. The main attraction to dark locations is their historical value rather than associations with death and suffering. Holocaust tourism contains aspects of both dark and heritage tourism .dark tourism is a sheer curiosity that pushes people to thread the road less traveled to search their answers, so travel by far has always been related to journey and to explore beautiful places. There are a lot of places in India. This research paper includes references to the promotion of dark tourism in India. The work includes references in the promotion of dark tourism in India, a destination that has largely failed to improve itself on Indian tourism market because this form of tourism promotions a destination .dark tourism attractions demonstrate demand but also consist of commemoration, historical references, narrative legacies, and populist heritage this tourism sites in some cases become one of few remaining elements of victims and tier testimonies. There is a lot of scope for developing dark tourism in India but taking some efforts and specific solutions to developed dark tourism in India. For this paper used secondary research methodology has been used for research for data collection, secondary data collected from the literature review also government agency data; online tourism news has been collected.
\end{abstract}

Keywords: Dark Tourism, Morbid, Populist Heritage, Historical Sites, Special Interest Tourism, Death and Tragedy

\section{Introduction}

The Indian tourism industry is one of the important contributors to the economy of the country. Tourism in India is growing rapidly. The world travel and tourism agency calculated that tourism generated 16.91 lakh crore 2018 and supported 42.67 million jobs, i.e., $8 \%$ of its total employment. The travel and tourism competitiveness report 2019 ranked india34 out of 140 countries overall Tourism is temporary short term movement of people to destinations outside the place of their residence tourism is undertaken for recreation, sight seen, pilgrims there are a lot of forms of tourism like sports tourism, adventure tourism, agro-tourism but in that paper, we discussed dark tourism in India. Dark tourism, also known as grief tourism, involves people taking keen curiosity in visiting paces that are historically linked to death and tragedy. Also, reminders of human suffering and bloodshed are subset through this concept sounds a bit weird. It is fast catching up with the trends, and in India, with such a long history, dark tourism automatically finds its spot. It is a sheer curiosity that pushes people to tread the road less traveled to seek answers travel by far always been related to journey and exploring beautiful places. With this type of tourism finding its ground, it only explains how the human mind cannot be tamed. 
Definition of Dark Tourism: Dark tourism involves tourist who visits the site of previous wars and battles, which are revived at the scene of previous violence, and their tour guides cite the examples of heroism, tragedy and personal suffering (Genova, 2008)

The term dark tourism was first mentioned by Foley Lennon (1996) in a special article of the international journal of the science of cultural and historical heritage. Dark tourism, with its main product death, is a prominent feature in the popular social panorama.

India has been blessed with a history of civilizations, kingdoms, and empires .these historical sits have been popular tourist destinations for a long time. But there are historical destinations which have been associate with death, tragedy associated with them. There are sites which can be labeled as dark tourism destinations because of some recent human interventions such as terrorist attacks or some natural calamity like earthquakes .in India, several locations are identified, which could serve the purpose of dark tourism.

\section{The Cellular Jail (Andaman \& Nicobar Islands)}

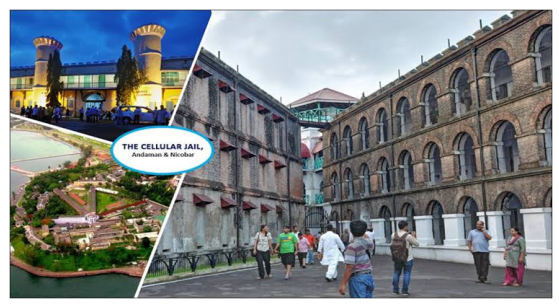

Source: www.trisonwheels.com

\section{Objectives of the Study}

In this research paper attempt, assessing dark tourism could be developed as other tourism in India. Some challenges that the dark tourism industry would face and suggest some steps to overcome this issue. The paper titled "dark tourism sites in India "seeks to address the following g objectives.

1. To study famous dark tourism sites in India

2. To suggests some suggestions would be helpful in the development of dark tourism in India.

\section{Research Methodology}

For this research paper, data has been collected from secondary sources. It includes online websites,
Wikipedia, the ministry of tourism, world travel, and the tourism council report, journals, and articles online also published electronic media from relevant literature.

Dark Tourism Sites in India - almost every type of tourism exists in India because of the diversity of culture, festivals, religions, and social conditions. The existence of dark tourism in India not much aware, but many sites fit in the dark tourism category.

1. The Cellular Jail, Andaman \& Nicobar the cellular jail is a constant reminder of our horrendous past when the British empire forcibly ruled the country and tortured thousands of innocent peoples who were fighting for freedom. During British rule, people who were sent to prison were known to be given the punishment of Kala Pani as there was no scope of escaping the isolated island, let alone the tight security. It is famous for the incarceration of Indian freedom fighters (including veer Savarkar) who were brutally tortured and forced to death.

2. Jallianwala bagh, Amritsar - talk about dark tourism in India and jallinwala bagh tops the list. Bloodstained walls, bullet-laden walls, and the gloomy ambiance of jallianwala bagh speak of the unfortunate tragedy it went through on 13 April 1919; on this dreadful day, people gathered to demonstrate peaceful protest against the arrest and deportation of two national leaders Satyapal and Sifuddin Kitchlew. Little did they know that they will be fighting for their lives and die a horrible death. On command o9f general dyer, the troops of the British army open fired without warning protestors and blocked entry and exit points to the place, leaving people stuck. Today, it is seen as a memorial of those who sacrificed their lives.

3. Kargil War Memorial, Ladakh - it is famous for the war between India and Pakistan in 1999 (Kargil war Drass war memorial is a place to soak the feeling of patriotism and valor of brave Indian soldiers who risks their lives to protect the nation from external threats, the saga of Kargil war started when Pakistan invaded some parts of Indian territory across the LOC threatening the only route connecting the place to Srinagar, 
to gain back the territory Indian army launched “operation Vijay “and gave a neck-to-neck fight to the enemies.

4. Bhangarh Fort, Alwar, Rajasthan - known as the most haunted fort in India, Chandigarh fort is a popular dark tourism place in India with a scary past. Legend has it that the place was cursed by a tantric priest who fell in love with princess Nanavati and attempted to woo her. But the princess didn't fell for him and got to know about his evil plans to have her. It sites famous for being a hotspot of paranormal activities.

5. Bhopal Disaster, Madhyapradesh - Bhopal has witnessed one of the world's worst industrial disasters, the case study of which is often done in reputed institutions and universities of the world. This gas leak incident happened in 1984 in the union carbide plant exposing over five lakhs people to toxic methyl isocyanate, the after-effects of which can still be seen in the area. It was famous for the leakage of methyl isocyanate from the union carbide plant.

6. Ramojirao Film City, Hyderabad - it, is the second-largest film city in India. It was inaugurated by producer Ramojirao in 1996. This film city is regarded as a creepy site in Hyderabad.according to claims of witnesses; mirrors are scribbled in weird Urdu words, leftover food is scattered all around the floor. The girls are seen as ghosted favorites are scary images make their changing room $\mathrm{s}$ and bathroom doors are knocked continuously.

7. Taj Palace Hotel, Mumbai - (2008 Mumbai Terrorist Attack) - one of the iconic jewels of India, taj palace hotel is an epitome of beauty, luxury, grace, and grandeur all rolled into one known for its high-end amenities and accommodation; this hotel is the apple of Mumbai eye. However, in 2008 this grand hotel witnessed an abominable act against humanity when terror organizations lakshare-taiba attacked it along with other locations of Mumbai. These series of terrorist attacks in Mumbai shocked the nation.

8. The Lambi Dehar Mines, Mussoorie - is famous recreational destinations for tourists, is also a place where dark tourism exists. The lambi Dehar mines in Mussoorie is one of the spookiest places in India. Millions of workers died in mine while working. Unusual deaths and activities have also been observed at this place.

9. Three Kings Church, Goa - is also famous for its paranormal activities. It is believed that three kings killed each other to rule over the property of this church, and people believe that the spirit of these kings in the premises.

10. Wagha border Crossing Points and Ceremonies, Punjab - the border between India and Pakistan showcases every evening ceremony where troops from both the nations on their side of the border march and display their might. The beating retreat ceremony has become a major tourist attraction in India, which attracts foreign tourists and domestic tourists in large numbers.

11. Shaniwarwada Fort, Pune - there is believed that a prince was unkindly murdered, and there have been various supernatural activities experienced by people nearby so; because of these situations, this place is considered as a part existence of dark tourism in India.

12. Dumas Beach, Surat, Gujarat - the beach covered with black sand, and various paranormal activities have been observed here. It is believed the person's walking around the beach at night has been dispersed this is also conspired as a dark spot in India.

\section{Challenges Faced by Dark Tourism in India}

1. Main problem of dark tourism in India is the lack of publicity and low publicity level.

2. Dark tourism is a new type of tourism, so very fewer people aware of these tourist sites, so many travel agencies are not able to provide proper service to visitors.

3. The dark destinations are inaccessible to the tourist due to less connectivity.

4. The government of tourism does not get enough support from the local's side to boost dark tourism and enhance the satisfaction level of dark tourists.

5. Also lack funds for the expansion of the tourism industry is also among the major obstructions faced by dark tourism. 
6. The dark tourism sites remain to be maintained, making them worst condition year by year, losing the charm and genuineness of the place it becomes more hunted and unacceptable.

\section{Suggestions for the Development of Dark Tourism in India}

- The first step to promote dark tourists in India with the help of audio-video as well as print media.

- For the development of dark tourism, organizations develop a proper circle of providing services to tourists like accommodation, food, providing them a guide, etc.

- Three people living near the dark tourism sites must have proper knowledge of places, and also, they must be protective and supportive toward tourists of the nearby places.

- The level of reaching and exploring the spot can be done when a circle is created for the tourists visiting the places, so there must be created proper circuits to get access to all the spots they want to.

- The citizens, travel organizations relating tourism activities must approach the government to change the existing policies and create new ones.

\section{Conclusions}

After going through the detailed study of dark tourism in India, it can be concluded that India is accomplished with dark destinations as well. Therefore, India holds the potential for dark tourism as people worldwide visit to wander through these sites. Further, to get more tourists for dark tourism in the Indian government should arrange for the necessary around these sites to come and know about all these sites. Theses dark sits also require to be promoted to make people aware of the existence of so many dark tourist sites in India. And India will experience a marginal increase in the tourism turnover of both domestic as well as international tourists flowing in to explore a wide variety of dark tourism product available in our country.

\section{References}

Bathory, Rebecca. Dark Tourism, Carpet Bombing Culture, 2018.
Bideci, M. "Is the 'Dark' Still Dark? The Evolution of Dark Tourism and Pilgrimage Destinations." Dark Tourism and Pilgrimage, edited by Olsen, Daniel, H. and Maximiliano Korstanje, CABI, 2020, pp. 16-24.

Buda, Dorina Maria. "Dark Tourism." The SAGE International Encyclopedia of Travel and Tourism, edited by Linda L. Lowry, Sage Publications, 2017, pp. 345-348.

Buda, Dorina Maria. "Routes in Dark Tourism." Affective Tourism: Dark Routes in Conflict, Routledge, 2015.

"Dark Tourism." Wikipedia, https://en.wikipedia. org/wiki/Dark_tourism

"Dark Tourism: Bizarre Form of Travel." India Tours, 2019, https://www.india-tours.com/ blog/dark-tourism-in-india.html

"Dark Tourism in India: Exploring Places with a Tragic Past." Trips on Wheels, https:// tripsonwheels.com/dark-tourism-in-indiaexploring-places-with-a-tragic-past/

Deutsch, Barbara. Tourists' Motivations for Engaging in Dark Tourism, Modul University Vienna, 2014.

Dey, Panchali. "Dark Tourism in India - Walking through the Alleys of India's Dark Past." Times Travel, 2018.

Lennon, John J. and Malcolm Foley. Dark Tourism, Continuum, 2000.

McDaniel, Kathryn N. Virtual Dark Tourism Ghost Roads, Palgrave Macmillan, 2018.

Olsen, Daniel, H. and Maximiliano Korstanje. Dark Tourism and Pilgrimage, CABI, 2019.

Sampson, Hannah. "Dark Tourism, Explained: Why Tourists Flock to the Sites of Tragedy." The Washington Post, 2019.

Sharply, Richard and Philip R. Stone. The Darker Side of Travel: The Theory and Practice of Dark Tourism, Channel View Publications, 2009.

Shetty, Priyanka. "Dark Tourism in India." International Journal of Disaster Recovery and Business Continuity, vol. 11, no. 1, 2020, pp. 622-627.

Singh, Sukhpreet, et al. "Dark Tourism in India Introduction, Places of Interest, Challenges and Strategies to Overcome Them." Imperial 
Journal of Interdisciplinary Research, vol. 2, no. 9, 2016, pp. 774-778.

Sneha, Kala, and G.S.Maheswari. "Contribution of Dark Tourism in India's GDP in Context of Taj Mahal and Cellular Jail." Adalya Journal, vol. 8, no. 10, 2019, pp. 422-434.

Stone, Philip R., et. al. The Palgrave Handbook of Dark Tourism Studies, Palgrave Macmillan, 2018.

Tarlow, Peter E. "Dark Tourism: The Appealing 'Dark' Side of Tourism and More." Niche Tourism: Contemporary Issues, Trends and
Cases, edited by Marina Novelli, ButterworthHeinemann, 2005, pp. 47-58.

"The Rise of Dark Tourism: Gruesome Destinations in India that can give you Nightmares." India TV News, 2019.

"What is Dark Tourism? Are you a Dark Tourist?", dark-tourism.com, https://www.darktourism.com/index.php/18-main-menus/ mainmenussubpages/599-what-is-darktourism

https://darktourists.com

https://www.dark-tourism.com

\section{Authors Details}

Swapnil P. Dhatrak, Assistant Professor, Department of Geography, LVH College, Nashik, Maharashtra, India, Email ID: swapnildhatrak45@gmail.com. 